\section{What is clinical leadership and why might it be important in dentistry?}

\author{
P. Brocklehurst, ${ }^{{ }_{1}}$ J. Ferguson, ${ }^{1}$ N. Taylor ${ }^{2}$ and M. Tickle ${ }^{1}$
}
IN BRIEF
- Provides an overview and critique of the different theoretical positions of clinical leadership.
- Explains how the changes in the NHS will directly impact general dental practitioners through the establishment of Local Professional Networks.
- Explores the potential role of 'clinical leadership' within Local Professional Networks.

The concept of leadership means different things to different people. At present there is no single definition of leadership nor an established theoretical approach. Despite this, leadership in the clinical environment is becoming increasingly cited as an important component in the transition of the National Health Service (NHS) and in the development of clinician led services. In medicine, clinical commissioning groups (CCGs) will soon be operational and the Department of Health (DH) seeks to establish a similar approach in dentistry, where local clinicians drive forward a quality agenda with a focus on patient outcomes. To facilitate this, the NHS Commissioning Board (NHSCB) are in the process of developing Local Professional Networks (LPNs) for dentistry. Given this shift towards localism and clinician led services it would appear that leadership will have a significant role in both medicine and dentistry. This paper explores what leadership is, before determining why it might be important in providing a clinician-led, patient-based and outcomes-focused service.

\section{INTRODUCTION}

Leadership is a nebulous concept and means different things to different people. ${ }^{1}$ This is because there is no single definition, no established theoretical approach or consensus about how best to identify leaders or help individuals become leaders. As such, leadership is difficult to define and difficult to measure, but is becoming increasingly cited as an important component in the transition and development of the National Health Service (NHS). ${ }^{2}$ Localism and clinician led services are concepts that are fundamental to the reorganisation of the NHS. ${ }^{3,4}$ The aim of this paper is to briefly discuss the approaches to the study of leadership and explore why it may be important in dentistry in the future.

\section{WHAT IS LEADERSHIP?}

Leadership has been described as a process of influence of one individual over a group of individuals. ${ }^{5}$ However, determining what knowledge, skills and attitudes

'Department of Dental Public Health, University of Manchester, Manchester, M15 6FH; ${ }^{2}$ North-West Deanery, Manchester, M1 3BN

${ }^{*}$ Correspondence address to: Dr Paul R. Brocklehurst Email: paul.brocklehurst@manchester.ac.uk

\section{Refereed Paper}

Accepted 8 November 2012

DOI: 10.1038/sj.bdj.2013.219

${ }^{\ominus}$ British Dental Journal 2013; 214: 243-246 a 'good leader' possesses is difficult and often relational and context specific. ${ }^{1}$ It is also influenced by the prevailing belief system or ontological paradigm in use within a particular culture.

The classification or taxonomy for understanding 'leadership' has developed in the literature across two broad themes: leadership as the individual and leadership as the relationship. ${ }^{6,7}$ Much of the early literature on leadership stems from the United States and took a predominantly individualistic perspective, attempting to determine specific attributes that made someone a good leader. ${ }^{8}$ These so-called trait theories have also been labelled as 'great man' or leader centric theories.

Differences in good 'leadership' are ascribed to innate 'trait-like' and 'statelike' differences within an individual that interact and produce 'leadership' as a behaviour. Meta-analyses has provided some evidence for trait-like individual differences; charisma, intelligence, ${ }^{9,10}$ extraversion, integrity, creativity and self-confidence have been identified as important attributes of a good leader. ${ }^{9,11}$ State-like individual differences include interpersonal and problem-solving skills and the ability to make difficult decisions. ${ }^{9}$

Many leadership programmes are still based on the assumption that acquisition of these qualities creates good leaders, despite reviews failing to establish a causal link. ${ }^{8}$ Equally there is scant evidence on the impact of leadership on outputs like productivity and as Hartley and Benington ${ }^{12}$ highlight, such theories tend to idealise individuals and assume that they have pre-eminent capacity and power'. Despite this, 'leadership as the individual' theories remain popular.

As the literature has evolved, academics have become more interested in leadership as a process rather than a defined set of traits or skills. Such models include those of Tannenbaum and Schmidt's ${ }^{13}$ where leadership is classified according to the different styles of behaviour that are observed. In the 1980s, this taxonomy was used to distinguish leaders from managers; leaders being seen as those who do the right thing, compared to managers who do things right. ${ }^{1}$ Leadership in this manner was seen as a process of influencing others $^{12}$ in the context of a relationship. This idea gained ground in the 1990s as tall hierarchical managerial structures within organisations were replaced with flatter networks. As such, leadership became important for specific time limited tasks or projects and so became more dispersed and less associated with a defined role in an organisation. ${ }^{12,14}$ This led to the 
development of contingency theories, ${ }^{15}$ which advocated that leaders need to adapt and change their behaviour according to their environment.

Modern theories of leadership have taken this approach a step further and see it as a process, which is informed by the task in hand, the people involved, the organisation where they work and the prevailing culture. In this sense, leaders are seen to be interdependent, contingent on others and affecting and being affected by the surrounding environment. ${ }^{16}$ In addition, leaders provide empowerment to develop the potential of others, while aligning their values with those of the organisation. ${ }^{17,18}$ This has become known as "transformational leadership'19 and formed the basis of the NHS leadership programme, which had a leadership qualities framework and a defined set of competencies (Fig. 1). ${ }^{20}$ The framework was composed of three categories: 'personal qualities', 'setting direction' and 'delivering the service', which were divided into 15 qualities (Table 1). Personal qualities are at the core of the framework, as NHS leaders are seen to draw upon these essential attributes. 'Setting direction' describes how the leader sets a vision for the future and 'delivering the service' explains how this vision is then implemented.

This framework is helpful as it focuses on leadership as a process and has undergone further revision to form the new Leadership Framework (LF). The LF provides a consistent approach to leadership development for staff in health and care irrespective of discipline, role or function, and represents the foundation of leadership behaviour. Further information on the LF can be found at www.leadershipacademy.nhs.uk/LF.

\section{IS LEADERSHIP IMPORTANT IN DENTISTRY?}

In medicine, Roland et al. ${ }^{21}$ argue that in addition to promoting high standards, doctors should take the lead, advocate healthcare system reforms and define the future characteristics of their profession. This builds on the 'new professionalism' being advocated by a number of key medical documents, ${ }^{21-24}$ which affirm 'the primacy of a just distribution of limited resources, patient welfare and autonomy, honesty and integrity, the importance of

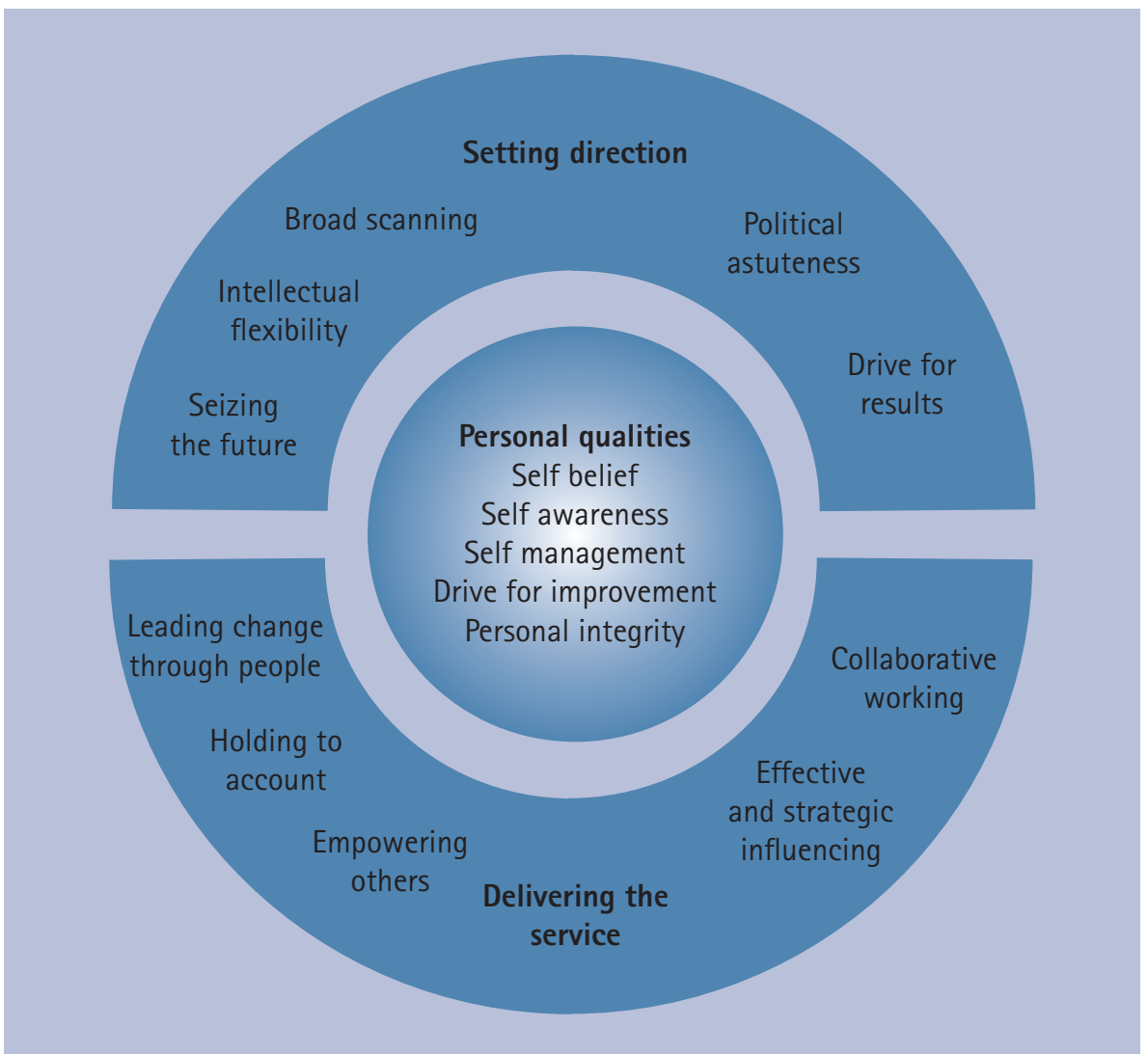

Fig. 1 NHS Leadership Qualities Framework. The LOF is ${ }^{\circ}$ NHS Institute for Innovation and Improvement, 2010. All rights reserved.

quality improvement, avoiding discrimination and reducing inequalities in access.'21 The King's Fund report Leadership and engagement for improvement in the $N H S^{2}$ has also recently been published and again advocates the importance of both leadership and engagement in driving the quality of patient care.

Although good clinical leadership was enshrined in Darzi's High quality care for all: NHS next stage review, ${ }^{25}$ this report had more influence in the management and commissioning structures of the NHS and in secondary care, compared to the provision of care by general dental practitioners (GDPs). However, this is all in the process of change as the NHS is reshaped by the Health and Social Care Act and the Localism Act. ${ }^{3,4,20,21} \mathrm{New}$ powers and responsibilities for health improvement and provision are causing a fundamental shift in the way that services are to be delivered and more importantly, the role of local clinicians in driving this change. In medicine, clinical commissioning groups (CCGs) will soon be operationalised and the NHS National Commissioning Board (NHSCB) wants to adopt a similar approach in dentistry, where clinicians take the lead in driving forward quality improvement and patient focused outcomes. The principle of clinician led services that is at the heart of the model in medicine will also drive the provision of care in dentistry.

To facilitate this the NHSCB are in the process of developing Local Professional Networks (LPNs) in dentistry. These will become a vehicle for clinician led commissioning and quality improvement. Guidance is still under development, but it is likely that LPNs will be composed of consultants in dental public health, dental commissioners, local GDPs, representatives of the local deaneries and successors to the dental practice advisors. The Department of Health argue that this represents a profound paradigm shift compared to current system for commissioning and service delivery. However, the extent to which GDPs on the LPNs will take the lead and become responsible for local service provision remains uncertain and will depend on whether the model will be as 'bottom-up' as medicine.

LPNs will be expected to provide input into the emerging health and wellbeing boards within local authorities and joint atrategic needs assessments (JSNAs). In addition, localism will become an 
important part of training and education, with LPNs working alongside the new Local Education and Training Boards (LETBs) to strategically plan and develop the workforce locally.

\section{LEADERSHIP AND DENTISTRY?}

Given this shift towards localism and clinician led services it would appear that leadership will have significant a role in both medicine and dentistry. However, there will be a number of challenges and opportunities. In medicine, the Academy of Medical Royal Colleges and NHS Institute for Innovation and Improvement developed the medical leadership competency framework and the medical leadership curriculum and this now forms the NHS Leadership Academy (Table 2). Although the GDC has placed more emphasis on leadership in education and training for dental professionals, ${ }^{26,27}$ there is a need to define and scope the leadership traits and behaviours that are required for developing leaders within the specific context of dentistry.

Leadership roles within LPNs must also be attractive for local clinicians to take on. This requires implementation of appropriate remuneration mechanisms to ensure GDPs neither lose money or profit from their LPN role; but this needs to be delivered within the challenges of financial austerity and the national operating model of the NHSCB. There is also the potential for conflicts of interest and self interest, with clinicians being both the commissioners and providers of care. This makes the appropriate governance arrangements and selection of LPN members critical, along with the correct number and proportion of primary and secondary care professionals to ensure a representative and balanced professional network.

GDPs are at the same time both business people and health professionals. ${ }^{28}$ While entrepreneurship and leadership does have some theoretical overlap, ${ }^{29}$ they can also be mutually exclusive. ${ }^{30}$ Kempster and Cope argue that the complex process of 'becoming' a leader happens through naturalistic learning. ${ }^{30}$ Environments and contextual experiences, which provide opportunities to participate in and observe leadership, are the dominant process in which emerging leaders develop their understanding and practice of leadership. To this extent GDPs are at a disadvantage given the limited scope for observation within the relative isolation of the

\begin{tabular}{|c|c|c|}
\hline Clusters & Quality & Description \\
\hline \multirow{5}{*}{$\begin{array}{l}\text { Personal } \\
\text { qualities }\end{array}$} & Self belief & $\begin{array}{l}\text { How the inner confidence of succeeding can overcome obstacles } \\
\text { for service improvement. }\end{array}$ \\
\hline & Self awareness & Knowing how your behaviour can affect others. \\
\hline & Self management & How managing your emotions can develop resilience. \\
\hline & $\begin{array}{l}\text { Drive for } \\
\text { improvement }\end{array}$ & $\begin{array}{l}\text { How a deep motivation to improve performance can make a real } \\
\text { difference to others' health and quality of life. }\end{array}$ \\
\hline & Personal integrity & $\begin{array}{l}\text { A strong commitment to openness, honesty, inclusiveness and high } \\
\text { standards in undertaking the leadership role. }\end{array}$ \\
\hline \multirow{5}{*}{$\begin{array}{l}\text { Setting } \\
\text { direction }\end{array}$} & Seizing the future & $\begin{array}{l}\text { Being prepared to take action now to shape and implement a vision } \\
\text { for the future. }\end{array}$ \\
\hline & $\begin{array}{l}\text { Intellectual } \\
\text { flexibility }\end{array}$ & $\begin{array}{l}\text { Ability to embrace and cut through ambiguity and complexity and be } \\
\text { open to creativity. }\end{array}$ \\
\hline & Broad scanning & Taking the time to gather information from a wide range of sources. \\
\hline & $\begin{array}{l}\text { Political } \\
\text { astuteness }\end{array}$ & $\begin{array}{l}\text { Commitment and understanding of diverse interest groups and power } \\
\text { bases within organisations and the dynamic between them. }\end{array}$ \\
\hline & Drive for results & $\begin{array}{l}\text { A strong commitment to improve performance and achieve positive } \\
\text { service outcomes for users. }\end{array}$ \\
\hline \multirow{5}{*}{$\begin{array}{l}\text { Delivering } \\
\text { the service }\end{array}$} & $\begin{array}{l}\text { Leading change } \\
\text { through people }\end{array}$ & $\begin{array}{l}\text { Communicating the vision and rationale for change and improvement, } \\
\text { and engaging and facilitating others. }\end{array}$ \\
\hline & $\begin{array}{l}\text { Holding to } \\
\text { account }\end{array}$ & $\begin{array}{l}\text { The strength of resolve to hold others to account for agreed targets } \\
\text { and to be held accountable. }\end{array}$ \\
\hline & $\begin{array}{l}\text { Empowering } \\
\text { others }\end{array}$ & $\begin{array}{l}\text { Striving to facilitate others' contributions and to share leadership, } \\
\text { nurturing capability and long-term development of others. }\end{array}$ \\
\hline & $\begin{array}{l}\text { Effective } \\
\text { and strategic } \\
\text { influencing }\end{array}$ & $\begin{array}{l}\text { Being able and prepared to adopt a number of ways to gain support } \\
\text { and influence diverse parties. }\end{array}$ \\
\hline & $\begin{array}{l}\text { Collaborative } \\
\text { working }\end{array}$ & $\begin{array}{l}\text { Being committed to working and engaging constructively with internal } \\
\text { and external stakeholders. }\end{array}$ \\
\hline
\end{tabular}

\begin{tabular}{|c|c|c|}
\hline Organisation & Uniform Resource Locator & Detail \\
\hline NHS Leadership academy & http://www.leadershipacademy.nhs.uk & $\begin{array}{l}\text { Aims to deliver outstanding leadership, at all levels and across } \\
\text { all health professions in the NHS }\end{array}$ \\
\hline Faculty of General DentalPractice (UK) & $\begin{array}{l}\text { http://www.fgdp.org.uk/courses/dentists/certifi- } \\
\text { cateindentalhealthservicesandleadership.ashx }\end{array}$ & $\begin{array}{l}\text { Aims to provide those involved in the provision of dental care } \\
\text { with a range of educational experiences that will advance } \\
\text { their knowledge and competence in the operational and } \\
\text { strategic management of dental services }\end{array}$ \\
\hline Faculty of Medical Leadershipand Management & http://www.fmlm.ac.uk/ & $\begin{array}{l}\text { Aims to promote the advancement of medical leadership, } \\
\text { management and quality improvement at all stages of the } \\
\text { medical career for the benefit of patients }\end{array}$ \\
\hline King's Fund leadershipdevelopment & http://www.kingsfund.org.uk/leadership/ & $\begin{array}{l}\text { Aims to develop leadership for individuals working in the new } \\
\text { health and social care environment }\end{array}$ \\
\hline NHS North West LeadershipAcademy & http://www.nwacademy.nhs.uk/ & Aims to develop new world leaders for health care \\
\hline NHS leadership programme & http://www.come2life.nhs.uk/ & $\begin{array}{l}\text { Aims to introduce standards, policies, incentives and a culture } \\
\text { for improving and inspiring leadership in the NHS }\end{array}$ \\
\hline
\end{tabular}


practice environment. Surgeries are not easily shared and the one-to-one relationship between dentist and patient means it is difficult to observe other clinicians ${ }^{28}$ and providing clinical leadership at a systems level is quite different from leading a practice team. If the model for medicine is adopted, the GDPs that will form part of the LPN will need to be given support and encouragement to look beyond their practice population in order to drive local commissioning.

In conclusion, the reorganisation of the NHS aims to provide a clinically-led, patient-based and outcomes-focused service. The establishment of dental LPNs as part of this change provides the profession with a hitherto undreamt of opportunity to have a very significant influence on how the NHS dental healthcare system is organised and delivered. To enable clinicians to make a success of this challenge they need appropriate support and training to develop their leaderships skills (Table 2). This evolving situation requires on-going academic support to develop an evidence base for the assessment and development of leadership skills and for the evaluation of the impact of clinical-leadership in the dental context.

1. Bennis W G, Nanus B. Leaders: strategies for taking charge. New York: Harper and Row, 1985

2. The King's Fund. Leadership and engagement for improvement in the NHS. London: The King's Fund, 2012. Online article available at http://www.kingsfund.org.uk/publications/ leadership-and-engagement-improvement-nhs (accessed on February 2013)

3. Health and Social Care Act 2010-12. Government Bill. Online information available at http://services. parliament.uk/bills/2010-11/healthandsocialcare. html (accessed February 2013).

4. Localism Act 2010-12. Government Bill. Online information available at http://services.parliament uk/bills/2010-2011/localism.html (accessed February 2013).

5. Northouse P G. Leadership theory and practice. 3rd ed. London: Sage Publications, 2007.

6. Day D V, Zaccaro S J. Leadership: a critical historical analysis of the influence of leader traits. In Koppes L L. (ed.) Historical perspectives in industrial and organizational psychology. pp 383-405. Mahwah, NJ: Lawrence Erlbaum, 2007.

7. Judge T A, Colbert A E, Ilies R. Intelligence and leadership: a quantitative review and test of theoretica propositions. J Applied Psycho/ 2004: 89: 542-552.

8. Swanwick T, McKimm J. What is clinical leadership. and why is it important? Clin Teach 2011; 8: 22-26.

9. Hoffman B J, Woehr D J, Maldagen-Youngjohn R, Lyons B D. Great man or great myth? A quantitative review of the relationship between individual differences and leader effectiveness. J Occup Organ Psych 2011; 84: 347-381.

10. Judge T A, Piccolo R F Transformational and transactional leadership: a meta-analytic test of their relative validity. J App/ Psychol 2004; 89: 755-768.

11. Judge T A, Bono J E, llies R, Gerhardt M. Personality and leadership: a qualitative and quantitative review. J Appl Psychol 2002; 87: 765-780

12. Hartley J, Bennington J. Leadership for healthcare. Bristol: The Policy Press, 2010.

13. Tannenbaum R, Schmidt W H. How to choose leadership pattern. Should a leader be democratic or autocratic - or something in between? Harvard Bus Rev 1958; 36: 95-101.

14. Spillane J. Distributed leadership. The Educational Forum 2005; 69: 143-150.

15. Hersey P, Blanchard K. Management of organizational behaviour: utilizing human resources. Englewood Cliffs, NJ: Prentice Hall, 1988.

16. Shamir B, Pillai R, Bligh M, Uhl-Bien M. Followercentred perspectives on leadership: a tribute to the memory of James R. Meindl. Greenwich: Information Age Publishing, 2007.

17. Bass B M, Avolio B J. Improving organizational effectiveness through transformational leadership. Thousand Oaks: Sage, 1993.

18. Alimo-Metcalfe B, Alban-Metcalfe J. Leadership in public organizations. In Storey J. (ed) Leadership in organizations: current issues and key trends. London: Routledge, 2004.

19. NHS Leadership Centre. NHS leadership qualities framework. London: Department of Health, 2003. Online article available at http://www.nhsbreakingthrough.co.uk/Pdfs/LOF-Framework.pdf (accessed February 2013).

20. NHS Institute for Innovation and Improvement. Leadership framework. Online information available at http://www.nhsleadershipqualities.nhs.uk (accessed February 2013)

21. Roland M, Rao S R, Sibbald B et al. Professional values and reported behaviours of doctors in the USA and UK: quantitative survey. BMJ Qual Saf 2011; 20: 515-521.

22. Irvine $D$. The performance of doctors: the new professionalism. Lancet 1999; 353: 1174-1177.

23. Medical Professionalism Project. Medical professionalism in the new millennium: a physicians' charter. Lancet 2002; 359: 520-522.

24. Royal College of Physicians. Doctors in society: medical professionalism in a changing world. Report of a working party of the Royal College of Physicians of London. London: RCP, 2005.

25. Professor the Lord Darzi of Denham K B E. High quality care for all: NHS next stage review final report. London: The Stationery Office, 2008. Online article available at http://www.dh.gov. uk/en/Publicationsandstatistics/Publications/ PublicationsPolicyAndGuidance/DH_085825 (accessed February 2013).

26. General Dental Council. Revalidation: postconsultation statement on revalidation for dentists. London: GDC, 2011. Online article available at http://www.gdc-uk.org/Dentalprofessionals/ Revalidation/Documents/Post-consultation\%20 statement\%200n\%20revalidation\%20for\%20dentists.pdf (accessed February 2013).

27. General Dental Council. Standards for dental professionals. London: GDC, 2005. Online article available at http://www.gdc-uk.org/dentalprofessionals/standards/Pages/default.aspx (accessed February 2013).

28. Taylor-Gooby P, Sylvester S, Calnan M, Manley G. Knights, knaves and gnashers: professional values and private dentistry. J Soc Policy 2000; 29: 375-395.

29. Perren L, Burgoyne J. Management and leadership abilities: an analysis of texts, testimony and practice. London: Council for Excellence in Management and Leadership, 2002.

30. Kempster $\mathrm{S}$, Cope J. Learning to lead in the entrepreneurial context. Int J Entrepren Behav Res 2010; 16: $5-34$ 